\title{
Writing Reflective Journal and Corrective Feedback: The Endeavors to Increase Students' Physics Achievement of Dynamic Fluids
}

\author{
Tomo Djudin \\ Tanjungpura University, Indonesia \\ tomo.djudin@yahoo.com
}

Received: June $22^{\text {nd }}, 2020$. Revised: July $25^{\text {th }}, 2020$. Accepted: August $3^{\text {rd }}, 2020$

\author{
Keywords : \\ Reflective Journal; Corrective \\ Feedback; The Uses of \\ Writing; Learning Outcome
}

\begin{abstract}
This study aims to determine the effectiveness of teacher' corrective feedback based on students reflective journal in the learning of dynamic fluids. The research method employed an experimental method with quasi-experimental nonequivalent control group design. The sample of eleventh grade of public senior high school SMAN 8 Pontianak consist of the XI-4 class as experimental group and the XI3 class as control group were drawn by using intact group random sampling technique. The achievement test consists of 25 multiple choice questions embracing factual, conceptual, and procedural knowledge was administered. After manipulating the treatment, it is concluded that the average of achievement of experimental group (64.27) and control group (52.13) were significant difference $(p<0.05)$. In addition, the extent of effectiveness of the treatment was in high category $(E S=1.02)$. The treatment should be provided to increase students' learning outcomes of any teaching-learning materials.
\end{abstract}

\section{INTRODUCTION}

Writing is work that deals with writing, expresses itself, conveys thoughts, gets feedback, and improves thinking [1] [2]. Simply stated, writing is a way to communicate through writing. The ability to write and read is an important learning activity to achieve scientific literacy which is the main target in the school environment [3] [4] [5]. Writing and reading are very important because they can make science lessons meaningful [6], develop critical thinking skills [7], and increase students' metacognitive knowledge [8]; influence brain development especially in parts that regulate important cognitive processes [9], has a positive effect on reading interest [10], and is assumed as a key for student success [11] [12] [13]. Although many science school teachers realize that more and more hands-on activities are not the solution to unsatisfactory science literacy [14], however, practical efforts to enhance students' reading and writing are neglected areas in science curricula [10] [15] [16].

A journal is one of four forms of personal writing that can be read by others [17]. Reflection is assessing oneself about strength, weakness, skill, problem, achievement, happiness, and solution [18]. In this study, reflective journal is a personal (informal) writing that is made by students and is self-assessing after students follow the learning process in class. Reflections expressed in journals can improve 
learning outcomes [19] [20] [21], and can improve intrapersonal intelligence. Writing reflective journal does not mean writing carelessly about what is happening and what is felt, but must have a clear line of thinking, with evidence or examples as illustrations of things that are reflected and use analytical approaches [22]. In education, reflective writing encourages students to think about what has been learned and how it is learned [23], namely things that are done or not done as students in terms of how to learn [24]. Al-Rawahi and Al-Balushi argued that journal writing makes students think in several cognitive processes, such as predictions, brainstorming, reflection, and asking questions [19]. Writing reflective journal can improve learning outcomes because students set their own learning strategies (selfregulated learners), monitor their own understanding to find, and overcome learning difficulties. The journal also helps students improve their practicum skills in two specific ways, namely: documenting experiences, and analytical practices by thinking of questions related to their laboratory experience [25].

Based on the information or clues written in the journal, teacher could provide the appropriate feedback. Feedback is information provided by someone (teacher) related to student performance or understanding [26]. There are two types of feedback, namely oral and written. Oral feedback can be done directly in learning, while written feedback tends to be done after learning. Feedback is very necessary so students know where the error is and then try to fix it [27]. Kluger and DeNisi meta-analyzes the effects of various aspects of feedback on student performance and found that all types of feedback improve student performance, except dropping feedback [26]. In addition, the corrective feedback provided by the teacher could increase higher student achievement than other types of feedback with the effect size of 1.13 in high category [26].

In this study, the feedback provided is corrective feedback. Corrective feedback is more appropriate given by the experienced teacher than by his/her own friends. It should be provided in an implicit way and must be clear so that the students are not shy. Selçuk et al. confirmed that learning strategies modeled explicitly by teacher could improve learning outcomes, attitudes, and learning motivation [28]. Students who get corrective feedback from the teacher get a higher score and corrective feedback is an essential aspect of learning [28] [29]. Cengiz and Karataş concluded that there are significant differences in the pre-service science teacher's pretest and posttest scores after writing reflective journals accompanied by feedback [30]. Students from different domains of knowledge showed the improvement in their learning outcomes regarding in self-reflection. Unfortunately, according to Lew and Schmidt, most of the firstlevel students in higher education are lack of experience in self-reflection [31]. Therefore, teachers in schools should do convince that corrective feedback, writing a reflective journal and self-awareness are vital factors in upgrading the students' learning outcomes.

The ability of students in Indonesia in writing and reading is still low [32]. This empirical fact is also supported from the PISA that revealed Indonesia on average ranked 62 out of 70 countries in terms of science, reading, and mathematics with scores of 403, 397, and 386 respectively. These capabilities are far below the average compared to other countries surveyed [33]. PISA also suggested a policy action which has to undertaken by the Indonesian government for improving the educational quality is to strengthen teacher subject matter competencies through stronger quality control at teacher training [33].

One of the essential subject matters of physics in schools is dynamic fluids. According to Walker, fluids are the basis of hydraulic engineering that is applied in a great many fields [34]. Unfortunately, a huge amount of students do not master, misunderstanding, disinterested, and lack of competencies about the topic. The results showed that high school students' scientific literacy on fluid dynamics materials in many schools in Indonesia were in the low category [35]. To increase students' achievement, for instance, Sabariasih, Jamzuri, \& Rahmasari applied the Snowball Throwing Model [36]. A practicum setfor laboratory was developed to improve students' scientific process skills and learning outcomes [37]. Jeliana et al. developed the teaching material on dynamic fluids based on scientific inquiry [38]. Mundilarto et al. applied the outdoor learning model through fieldwork to improve students' achievement in dynamic fluids [39]. 
In the context of this study, based on interviews with the teacher, students' negative learning symptoms of the $11^{\text {th }}$ grade of public senior high school SMAN 8 Pontianak occurred while learning physics especially fluids before. Most of them lacked independence and confidence about the subject matters they learned, feeling disinterested when learning the materials, and quickly forgetting the essential concept and principles they have learned. The success of rate in academic achievement of this topic do not reach the minimum standard of passing rate $(\mathrm{KKM})$ i.e $75 \%$ per class. The percentage of classes with passing rate less than $75 \%$ is still quite low. The empirical learning problems become a focus he handled. In addition, he also confirmed that corrective feedback and reflective journal are rarely to apply in the learning of physics including dynamic fluids.

Although efforts to upgrade learning outcomes in the learning of dynamic fluids and the teachers' corrective feedback and reflective journal had been separately conducted in some previous investigations, however, only a few studies that integrating corrective feedback based on reflective journal with teaching learning models usually applied in their classes. Most teachers sometimes neglected these forceful learning activities. In addition, which teaching method effective in the learning environment, even with decades of research, has not yet to be resolved [40]. This study aimed to assess the extent of effectiveness of corrective feedback based on a reflective journal on learning outcomes of dynamic fluids of eleventh class students of public senior high school in Pontianak.

\section{METHOD}

The research method employed a quasi-experimental method with pre-posttest nonequivalent control group design [41]. The target population of this research was the 11th grade students (15 until 17 years old) of public senior high school of SMAN 8 Pontianak, West Kalimantan, Indonesia ( $N=147$ ) enrolled in the academic year 2018/2019. The entire students have never been instructed on materials of the dynamic fluids before. The sample consists of the XI-4 class as the experimental group (33 students) and the XI-3 class as the control group (35 students) were drawn by using the intact group random sampling technique.

The independent variable was treatments that applied to the two groups. The treatments reflected the research questions. Integrating teachers' corrective feedback based on the journal students wrote with a direct instruction model in the learning of dynamic fluids was treatment applied to the experimental group. The only direct instruction model applied in the learning of dynamic fluids was treatment was applied to the control group.

The students' reflective journal in this investigation was modified from the reflective journal writing model developed by Al-Rawahi \& Al-Balushi [19]. In this study, the structure of students' reflective journal exposed in a specific book of a homework assignment that regarding; (1) the teacher's learning objectives that he/she could achieve after the instruction; (2) the explained subject matters that are unintelligible or unplausible; (3) the individual solutions of homework exercises the teacher assigned; (4) the exercise items are assumed difficult to solve and the causes as well; and (5) the comments or suggestions for teachers to improve his/her teaching-learning process. Based on the things expressed explicitly in the students' reflective journals, the corrective feedback provided. The types of corrective feedbacks regarding the comments, reexplanation, correct solution provided individually in the book of a homework assignment, and/or classically in front of the class before, during, or after the instruction. The dependent variable was the overall (average) score on pre-and posttest of students' achievement of dynamic fluids.

Their instrument administered in this study is the pretest and posttest achievement tests that are equivalent. A lecturer and two physics teachers are asked to judge firstly the compliance with indicators with items, appropriateness of aspects covered in the blueprint, the clarity of sentences (words) of the items. It is found that the coefficient Cronbach Alpha of content and construct validity is 0.82 (in satisfactory category). The revisions of the achievement tests were performed based on the expert comments and suggestions. The content of the subject matters was Continuity's principle and the 
application of Bernoulli's principle. The 25 items multiple-choice achievement test consists of 4 items of factual knowledge, 13 items of conceptual knowledge, and 8 items of procedural knowledge. The empirical reliability of the test assessed by using the correlation of point-biserial reliability was 0.76 (in sufficient category).

The students who were absent during administering on pre-and posttest were excluded from data analysis. Due to the data were normally distributed, the parametric statistics should be used. Comparisons (t-test, $\mathrm{p}<0.05$ ) made between the two groups showed a significant difference in the scores of students' dynamic fluids. The extent of effectiveness of the teachers' corrective feedback based on journal students written was assessed by using the Effect Size [42], namely ES = difference between the means, M1 - M2, divided by the standard deviation of either.

\section{RESULTS AND DISCUSSIONS}

Pretest

Scores (interval data) gathered from the two groups was analyzed by parametric t-test. Pretesting concluded that there was no significant difference of average of academic achievement of dynamic fluids between experimental groups and control group $(t=0.93, \operatorname{sig}=0.771, p>0.05)$ as shown in Table 1 .

Table 1. Pretest Means of Achievement

\begin{tabular}{|c|c|c|c|c|c|c|}
\hline Group & $\mathbf{N}$ & Mean & SD & df & t-value & Sig \\
\hline Experimental & 33 & 27.07 & 9.61 & \multirow{2}{*}{66} & \multirow{2}{*}{0.93} & \multirow{2}{*}{0.771} \\
\hline Control & 35 & 27.73 & 9.08 & & & \\
\hline
\end{tabular}

The result concluded that there are no significant differences in students' academic achievement of dynamic fluids between the two groups before treatment. It means that students' achievement before manipulating the treatment is not significantly different.

Posttest

The result revealed that there are significant differences in students' academic achievement of dynamic fluids after manipulating the treatment as shown in Table 2.

Table 2. Posttest Means of Achievement

\begin{tabular}{|c|c|c|c|c|c|c|}
\hline Group & $\mathbf{N}$ & Mean & SD & df & t-value & Sig \\
\hline Experimental & 33 & 64.27 & 14.66 & \multirow{2}{*}{66} & \multirow{2}{*}{$2.59^{*}$} & \multirow{2}{*}{0.001} \\
\hline Control & 35 & 52.13 & 15.05 & & & \\
\hline
\end{tabular}

* significant at the 0.05 level

By using Cohen's formula of effect size, the analysis found that the extent of effectiveness of teachers' corrective feedback based on the journal on dynamic fluids achievement is 1.02 (in high category).

There are three domains of knowledge developed in the achievement test of dynamic fluids in this study, they are; factual, conceptual, and procedural knowledge. Those domains of knowledge in compliance with the aims of the curriculum 2013 presently implemented in Indonesia. It is acknowledged that after having received the teaching-learning processes of physics, senior high school students should acquire four dimensions of basic knowledge in standard competencies, they are; factual knowledge, conceptual knowledge, procedural knowledge, and metacognitive knowledge [5]. 
Simply stated, factual knowledges seek recall information from textbook or various sources. Conceptual knowledge ask students to describe the factual information and to become aware of the relationships between the elements of a larger structure. Procedural knowledge assess the learners' ability to choose from well-established methods and select the most appropriate algorithm, technique, or criteria based on the particular situation. Finally, metacognitive knowledge ask learners to reflect on experiences and identify possible areas of improvement. According to the result of investigation, the reflective journal students's written in this study could increase self-awareness as an essential factor of metacognitive knowledge [19].

This study found that averages of pretest between experimental group (27.73) and control group (27.07) were not a significant difference. The mean of the postest of the experiment group (64.27) was higher than the control group (52.13). It means that the gain scores are 37.20 for the experimental group and the amount of 24.40 for the control group. However, it is not surprising that the students' learning outcomes were still low. According to the theoretical views and findings of numerous studies, learning outcome is related to the interest [43] [44]. Woolfolk argued " this is not always an easy or even a desirable strategy; there are times when students must master basic skills that hold no intrinsic interest for them" [44].

Through the use of a survey of 191 students of the early years of secondary school. The identified influential factors which cause students to be interested or disinterested in physics, they are : (1) one reason that so many people have such a lack of familiarity with physics is the fact that very few people ever actually take a physics course; (2) another possibility for the small number students enrolling in physics classes is the means by which most high schools arrange their science program. Many high school students regarded physics as 'the most difficult science'. Therefore, they would decide not to take physics in place of a less difficult elective and would simply not be in science long enough to take a physics course; (3) Most other high school science courses rely on a large amount of memorization. Physics, on the other hand, deals more with quantitative skills and connections or relationships between concepts. The students who have done well in other science courses could possibly go into a physics course with the same mentality that was previously successful. Those students could then become frustrated the "methods" that work for biology or chemistry do not work for physics; (4) Finally, many students do not take a physics course because they are admittedly worried about struggling with the class or even failing the class because of the extreme level of difficulty that they associate with physics. Related to the interest, Haussler et al. explained that interest is understood as a trait of the individual, i.e. as an enduring preference for a particular field of knowledge or action (known as individual or personal interest) [45]. In addition, interest is interpreted as a state that is related to the specific appeal of a given situation (known as situational interest or interestingness. Furthermore, personal interest (personal interest) is specific to individuals, develops slowly, and tends to have a long-term effect on one's knowledge and values. Whereas situational interest (situational interest) is spontaneous, fleeting, and may only have a short-term effect on individual knowledge and values [46].

Lavonen et al. argue that teachers can seek changes in situational interests for the personal interests of students by selecting content, context, and teaching methods [47]. Therefore, it is important for a teacher or lecturer to know the content (content), context, and interests of students. It can be summarized that interest can be seen as an integrated component of psychological, social, and physical factors that are interrelated in a particular learning situation, including in the learning of dynamic fluids. To make the teaching and learning materials could be interesting, Schraw, Flowerdwy, and Lehman suggested that teachers should encourage pupils to be active and motivated learners and provide relevance cues or feedback for pupils [46]. Kelly argued that a lack of student interest and motivation can be quite a challenge for teachers to combat [48]. She noted that incentives, rewards, corrective feedback can motivate students to engage while achieving the expected learning outcomes. When students are involved in actively in learning activities, the information being taught can acquire more meaning and spark more interest.

The analysis found that the extent of the effectiveness of teachers' corrective feedback based on the journal on dynamic fluids achievement is 1.02. It showed that instruction integrated with corrective 
feedback based on reflective journal has high effectiveness in improving student learning outcomes compared to the conventional model. Cengiz and Karataş concluded that there were significant differences in the pre-service science teacher's pretest and posttest scores after writing reflective journals accompanied by feedback [30]. In contrast, Lew and Schmidt asserted that there was no significant increase in test scores [31]. The reasons are teachers rarely provide feedback and students are less experienced in self-reflection as well. Even more, most of the first level students in higher education are inexperienced in self-reflection regarding the better ways for learning [31]. On the contrary, Selfe et al. declared that students' reflective journal was not highly contributed to raising the gifted students' achievement [31]. They assumed that it just assisted them to develop their abstract thinking skills and to conceptualize the technical strategy in case of writing activity and problem-solving as well. They become easier to develop a definition personally that more intelligible than the textbook technical definitions mentioned.

The result found that there a significant difference in students' academic achievement of dynamic fluids after the manipulating of the treatments between groups. It can be concluded that there is a significant relationship between good learning habits and students' achievement in physics. The students who always do the homework tasks and write the reflective journal could be assumed as good learning habits. The explicit corrective feedbacks i.e. comments, suggestions, the improved solutions the teacher provided individually and/or classically could improve the students' outcomes [49]. According to Alcantara and Roleda, feedback is very necessary so that students know the location of their mistakes and then try to fix them [27].

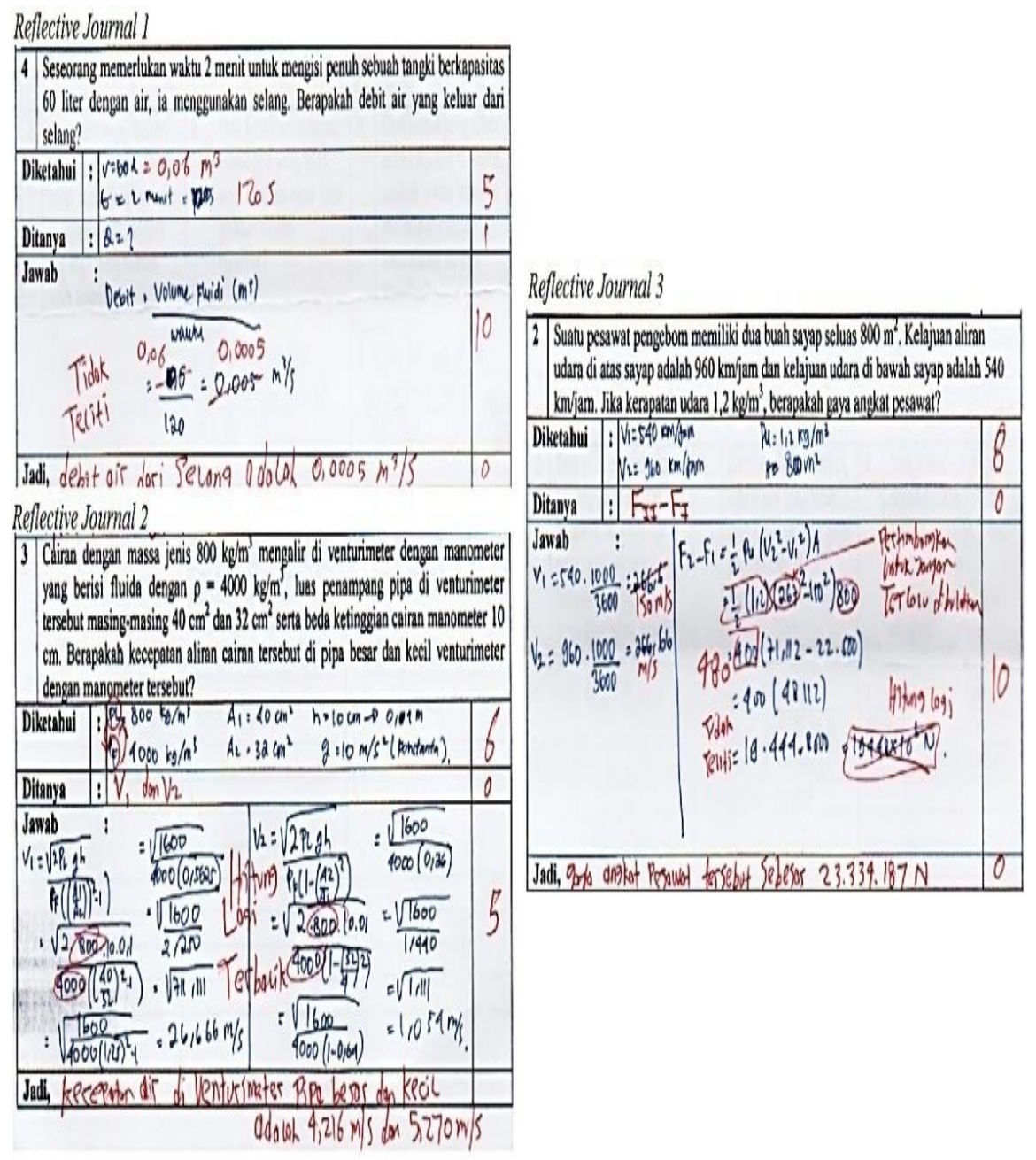

Fig 1. The Exemplars of Corrective Feedback of the Solution on Students' Reflective Journals 
Here we exposed the only one exemplar of teacher's corrective feedbacks regarding the solution of a word problem used the procedural knowledge (written in red color) as shown in Figure 1. As seen in Figure 1, after the treatment in Reflective Journal 1,2, and 3, it is confirmed the ability to solve word problems in dynamic fluids in the experimental group is significantly different from the control group. It means that the teacher's corrective feedback relating to the correct solution regarding using the procedural knowledge to solve the word problems is one of the determinant factors to increase the learning outcomes. The students who received appropriately corrective feedback will show better performances than the unreceived. It can make students more independent, self-confident, selfregulated, and have good self-efficacy in learning [29]. Feedback and opportunity for reflection are also cited as powerful writing features that support learning. The "systematic reflection," a specific set of journal-keeping techniques that have been found useful in helping teachers take control of their own professional development. Thus, it is confirmed that the integration corrective feedback with reflective journal potentially contributed to the students' performances.

Rivard's study summarised that they are two writing strategies commonly employed in science learning, namely; expository writing and expressive writing, or the combination of these two writing modes [50]. Expository writing includes tasks like note-taking, summarizing, and analyzing. whereas expressive writing is the informal kind of writing associated with journals and diaries. Thus, reflective journal as adopted in this study is one type of expressive writings. The act of writing requires students to gather, organize, and formulate old and new knowledge and record their ideas. Writing, thus, provides a method for recording or eliciting students' thoughts [13]. Swinson confirmed the use of writing as an aid for teaching and learning that is supported by the results of cognitive research and described briefly as below [51].

\section{Writing is a strategy for eliciting preconceptions}

The act of writing requires students to gather, organize, and formulate old and new knowledge and record their ideas. Writing, thus, provides a method for recording or eliciting students' thoughts [15] [52]. Mason argued that what is going on inside students' heads is endemic to teaching [51]. When discussing preconceptions, Postner et al. suggested that new information is fitted or assimilated into an existing cognitive structure [53]. As they put it, what students learn and what they are capable of learning depends on the mental models each of them has developed. Sometimes student's preconceptions are inaccurate, hence they have misconceptions and these do not offer a sound basis for the construction of new knowledge. It is important to realize that many approaches to instruction fail to correct misconceptions, for if new knowledge is presented while the misconceptions still exist, effective learning may not take place. It is obvious then that when previously learned knowledge is inaccurate, the goal of instruction must first be corrected the misconception by modifying the schema concerned and then, and only then, introduce the new information [51].

\section{Writing as a diagnostic tool}

Classroom research supported the use of writing prompts for classroom diagnosis. These prompts are statements developed by the teacher and used to solicit a written response from the student. Examples of phrases that can be used to create writing prompts are:

In your own words, describe why ....

Explain the process you used to ....

In your own words, define ....

Explain the errors you made in solving the problem of ....

These prompts can be used at any stage during the lesson. Used before teaching begins, the prompts enable the teacher to determine the misconceptions being brought to the lesson. Used during the lesson, they help clarify ideas and indicate when understanding is inaccurate. Used at the end of a lesson, they enable the teacher to assess the level of understanding achieved, identify inaccuracies and direct the planning of the next lesson.

\section{Writing as a knowledge construction}

Teacher and text are an essential source of information which may be used to construct new knowledge. Opportunities need to be provided that allow students to actively use and explore information in order 
to understand it. During these interaction activities, the students' existing knowledge structures undergo modification to accommodate the new information resulting in the creation of new knowledge [53]. A student who is actively building connections between what is being learned and what is already known is creating new knowledge. However, the mere memorization information obtained from the teacher or the textbooks doesn't constitute effective learning. Learning can be thought of as the change from knowing what to knowing how and our ability to remember depends on the nature of the information we have previously acquired and how the information is linked to it. Those who are efficient at constructing new knowledge acquire an understanding that is more general than memorization of specific steps or facts and this was often achieved by engaging in a process of self-explanation. Writing activities should be used on a regular basis two or three times each week if they are to be effective [54]. Simply stated, making notes of graphic post organizers as a knowledge construction and consequently could upgrade the quality of science instruction.

\section{CONCLUSION AND SUGGESTION}

Based on data analysis, it is concluded that instruction integrated with corrective feedback based on reflective journals highly contributed to students' learning outcomes. To enhance students' learning outcomes, teachers should provide appropriate corrective feedback in accordance with any types of students' writing activities. Teachers are suggested to cultivate self-awareness and self-regulated through writing a reflective journals as a means for developing metacognitive knowledge. Using students' interest and self-concept as the covariate variables in the analysis of experimental design might be a potential focus in the future study.

\section{REFERENCES}

[1] English Club. (2018). What is writing?. (Online), (https://www.english club.com/writing/what.htm.

[2] KBBI. (2017). (Online), (https://kbbi.web.id/tulis, Accessed 26 February 2018.

[3] K12 Reader. (2016). The relationship between reading and writing. (Online),(http://www.k12reader.com/the-relationship-between-reading-and-writing/.

[4] Marquette University. (2011). What makes writing so important?. (Online), (http://www.marquette.edu/wac/WhatMakesWritingSoImportant.shtml, Accessed 22 February 2018.

[5] Permendikbud. (2016). Standar Kompetensi Lulusan Pendidikan Dasar dan Menengah. (Online), (bsnp-indonesia.org/wp.../04/Permendikbud_Tahun2016_Nomor020_Lampiran.pdf, Accessed 22 Februari 2018.

[6] Glynn, S. M., \& Muth, K. D. (1994). Reading and writing to learn science: Achieving scientific literacy. Journal of research in science teaching, 31(9): 1057-1073.

[7] Quitadamo, I. J., \& Kurtz, M. J. (2007). Learning to improve: using writing to increase critical thinking performance in general education biology. CBE-Life Sciences Education, 6(2): 140-154.

[8] Djudin, T., \& Amir, R. (2018). Integrating SQ4R Technique with Graphic Postorganizers in the Science Learning of Earth and Space. Jurnal Pendidikan IPA Indonesia, 7(1): 76-84.

[9] Santrock, J. W. (2011). Educational psychology 5th edition. New York: McGraw-Hill.

[10] Ryan, L. (2012). Students' attitudes towards corrective feedback in the second language classroom. Dublin: Trinity College.

[11] Gaskins, I. W., Guthrie, J. T., Satlow, E., Ostertag, J., Six, L., Byrne, J., \& Connor, B. (1994). Integrating instruction of science, reading, and writing: Goals, teacher development, and assessment. Journal of Research in Science Teaching, 31(9): 1039-1056.

[12] Halloun, I. (1996). Schematic modeling for meaningful learning of physics. Journal of Research in Science Teaching: The Official Journal of the National Association for Research in Science Teaching, 33(9): 1019-1041.

[13] Reynolds, J. A., Thaiss, C., Katkin, W., \& Thompson Jr, R. J. (2012). Writing-to-learn in undergraduate science education: a community-based, conceptually driven approach. $C B E-$ Life 
Sciences Education, 11(1): 17-25.

[14] Yore, L. D., Shymansky, J. A., Henriques, L., Chidsey, J. L., \& Lewis, J. (1997). Reading-to-learn and writing-to-learn science activities for the elementary school classroom. In Proceedings of the 1997 Annual International Conference of the Association for the Education of Teachers in Science (pp. 40-72).

[15] Fulwiler, B. R. (2011). Writing in science in action: Strategies, tools, and classroom video. Heinemann.

[16] Yore, L. D., \& Shymansky, J. A. (1991). Reading in science: Developing an operational conception to guide instruction. Journal of Science Teacher Education, 2(2): 29-36.

[17] Tarigan, H. G. (2008). Menulis sebagai suatu keterampilan berbahasa. Bandung: Angkasa.

[18] The Open University. (2018). Self reflection. (Online), (http://www.open .ac.uk/choose/unison/develop/my-skills/self-reflection, Accessed 26 January 2018

[19] Al-Rawahi, N. M., \& Al-Balushi, S. M. (2015). The Effect of Reflective Science Journal Writing on Students' Self-Regulated Learning Strategies. International Journal of Environmental and Science Education, 10(3): 367-379.

[20] Ndiewo, P. O., Raburu, P., \& Aloka, P. J. O. (2016). Influence of learner reflection on academic performance of Kenyan secondary school students. International Journal of Psychology and Behavioral Sciences, 6(3): 128-132.

[21] Yusuff, K. B. (2015). Does self-reflection and peer-assessment improve Saudi pharmacy students' academic performance and metacognitive skills?. Saudi Pharmaceutical Journal, 23(3): 266-275.

[22] University of Birmingham. (2014). A short guide to reflective writing. Birmingham: University of Birmingham.

[23] Monash University. (2018). Reflective writing in education. (Online), (https://www.monash.edu/rlo/assignment-samples/education/education-reflective-writing, Accessed 26 February 2018.

[24] Henter, R., \& Indreica, E. S. (2014). Reflective journal writing as a metacognitve tool. International Scientific Committee, 533.

[25] Towndrow, P. A., Ling, T. A., \& Venthan, A. M. (2008). Promoting inquiry through science reflective journal writing. Eurasia Journal of Mathematics, Science and Technology Education, 4(3): 279-283.

[26] Hattie, J., \& Timperley, H. (2007). The power of feedback. Review of educational research, 77(1): $81-112$.

[27] Alcantara, K. R., \& Roleda, L. S. (2016, March). The Use of Fast Feedback Methods in Teaching Physics for Grade 7 Science. In Proceedings of the DLSU Research Congress (Vol. 4).

[28] Selçuk, G. S., Sahin, M., \& Açıkgöz, K. Ü. (2011). The effects of learning strategy instruction on achievement, attitude, and achievement motivation in a physics course. Research in Science Education, 41(1): 39-62.

[29] Ahmad, I., Saeed, M., \& Salam, M. (2013). Effects of Corrective Feedback on Academic Achievement of Students: Case of Government Secondary Schools in Pakistan. International Journal of Science and Research, 2(1): 36-40.

[30] Cengiz, C., \& Karataş, F. Ö. (2015). Examining the effects of reflective journals on pre-service science teachers' general chemistry laboratory achievement. Australian Journal of Teacher Education, 40(10): 8.

[31] Lew, M. D., \& Schmidt, H. G. (2011). Self-reflection and academic performance: is there a relationship?. Advances in Health Sciences Education, 16(4): 529-545.

[32] Wakhidah, N. (2012). Keterampilan membaca dan menulis dalam meningkatkan berpikir kritis dan literasi sains. (Online), (https://osf.io/56kem/?action=download, Accessed 5 February 2018.

[33] PISA. (2015). Programme for international student assessment (PISA) results from PISA 2015 Indonesia. (Online), (https://www.oecd.org/pisa/PISA-2015-Indonesia.pdf, Accessed 4 January 2018.

[34] Walker, J. (2008). Halliday and Resnick fundamental of physics extended eight edition. New Jersey: John Wiley and Sons (Asia) Pte Ltd.

[35] Parno, P., Yuliati, L., \& Munfaridah, N. (2017). The profile of high school students' scientific literacy on fluid dynamics. 4th International Seminar of Mathematics, Science and Computer Science Education IOP Publishing IOP Conference Series: Journal of Physics, doi :10.1088/1742- 
Writing Reflective Journal and Corrective Feedback: The Endeavors to Increase Students’ Physics...

Tomo Djudin

6596/1013/1/012027.

[36] Sabariasih, D. P., Jamzuri, J., \& Rahmasari, L. (2015). Remediasi Pembelajaran Fisika dengan Model Snowball Throwing Pada Materi Fluida Dinamis Kelas XI di SMA Negeri 6 Surakarta. In Seminar Nasional Fisika dan Pendidikan Fisika Ke-4 2015. Sebelas Maret University.

[37] Alfiyah, S., Bakri, F., \& Raihanati, R. (2016). Pengembangan Set Praktikum Fluida Dinamis untuk Sekolah Menengah Atas (SMA) Kelas XI. Jurnal Penelitian \& Pengembangan Pendidikan Fisika, 2(2): 47-56.

[38] Jeliana, V. S., Nurdin, B., \& Makmur, S. (2016). Pengembangan bahan ajar fisika pada materi fluida dinamis berbasis scientific inquiry untuk meningkatkan hasil belajar. Jurnal Pendidikan Fisika, 5(1): 7-11.

[39] Mundilarto, Pamulasari, \& Enggar, H.(2017). Outdoor learning model through fieldwork to improve physics achievement in dynamic fluids. Journal of Turkish Science Education (TUSED), 14(3): 73-86.

[40] Chua, C. L., \& Heng, R. K. K. (2014). Students' ratings of teaching effectiveness: what do students tell us about their teacher education lecturers? [online].

[41] Sugiyono. (2016). Metode penelitian pendidikan (Pendekatan kuantitatif, kualitatif, dan R\&D). Bandung: Alfabeta.

[42] Cohen, R. (1988). Effect Size (ES). Retrieved December 4, 2012.

[43] Restasari, Arini, W., \& Ariani, T. (2017). Hubungan minat belajar terhadap hasil belajar fisika siswa kelas XI MA Mazro'illah Lubuklinggau tahun ajaran 2015/2016. MIPA Repositori STKIP PGRI Lubuklinggau, 1-17.

[44] Woolfolk, A. E. (1995). Educational psychology ( $6^{\text {th }}$ edition). USA : Allyn \& Bacon, Inc.

[45] Häussler, P. (1987). Measuring students' interest in physics-design and results of a cross-sectional study in the Federal Republic of Germany. International Journal of Science Education, 9(1): 7992.

[46] Schraw, G., Flowerday, T., \& Lehman, S. (2001). Increasing situational interest in the classroom. Educational Psychology Review, 13(3): 211-224.

[47] Lavonen, et.al. (2005). Pupil interest in physics: A survey in Finland. Retrived January 15, 2018, from: https://www.educationandemployers.org/.../pupil-interest-in-physics

[48] Kelly, M. (2017). What to do when students lack interest. helping students get interested and motivated. Retrived February3, 2018, from: https://www.thoughtco.com/when-students-lackinterest-8086.

[49] Abbas, A., \& Hidayat, M. Y. (2018). Faktor-faktor kesulitan belajar fisika pada peserta didik kelas IPA sekolah menengah atas. Jurnal Pendidikan Fisika, 6(1): 45-50.

[50] Rivard, L. O. P. (1994). A review of writing to learn in science: Implications for practice and research. Journal of Research in Science Teaching, 31(9): 969-983.

[51] Swinson, K. (1992). Writing Activities as Strategies for Knowledge Construction and the Identification of Misconceptions in Mathematics. Journal of Science and Mathematics Education in Southeast Asia, 15(2): 7-14.

[52] Armbruster, B. B., Anderson, T. H., \& Ostertag, J. (1991). Teaching text structure to improve reading and writing. The Reading Teacher, 26(8): 130-137.

[53] Posner, G. J., Strike, K. A., Hewson, P. W., \& Gertzog, W. A. (1982). Accommodation of a scientific conception: Toward a theory of conceptual change. Science education, 66(2): 211-227.

[54] Mitchell, H., \& Ramage, K. (2005). Learning to teach science with writing: Implementation of the Seattle elementary expository writing and science notebooks program in typical classrooms. Inverness Research Inc. Retrieved June 21, 2017 from http://www.invernessresearch.org/abstracts/ab20059_Rpt_SeattleNotebks_ElemSciWrt.ht 